\title{
Social Customs and Beliefs among the Kadars of Anamalai Region in Coimbatore District
}

\author{
P. Karthika* \\ Assistant Professor and Head, PG and Research Department of History, Vellalar College for Women, Erode, India; \\ pkkarthika@gmail.com
}

\begin{abstract}
The social organization of the tribes in India is very diverse and often quite complicated. This is quite natural as they come from so many different races and cultures which are at various stages of development. They have also been much influenced by the surrounding superior cultures. Among the nomadic food gathering tribes, the social structure is based mainly on the natural family. Usually several such families, united by ties of kinship, form a local group. They live together, hunt and collect together and share out among themselves what they have gathered. They have obligations towards each other, and support each other in want, sickness and old age. Social life, however, is not entirely restricted to the local groups. The local groups meet occasionally to celebrate feasts, for the arrangement of marriages and for other important matters. This paper focuses on social organization, customs and culture of the Kadars, the primitive hill tribes of Anamalai region in Coimbatore District.
\end{abstract}

Keywords: Indigenous, Marginalized, Negiritos, Nomadic, Primitive, Settlements, Venerate

\section{Introduction}

India is a vast beautiful land with a long and eventful history. For thousands of years different communities of men and woman have lived in this subcontinent, cultivating lands, fostering industries, practicing arts and crafts and creating indigenous culture. A variety of civilization flourished here and as a result, India has become the home of many different races, speaking numerous, diverse tongues and following several customs and habits. Besides this cultural glory, many primitive communities are still prevalent with their own culture. These marginalised communities occupy a limited page in the cultural history of India pertaining to each state or region. These primitive groups are called tribals. Under the preponderant influence of the Marxian and the Annals schools of thought, the writing of social history has been scientifically forced up. Therefore there is a perceptible shift in the content and perspective of historical writing. The concept of history from the bottom-up is gaining ground almost everywhere. So the study of tribal society and culture has been a major pre-occupation of anthropologists in India.

The British had followed the policy of keeping the tribes away from the main stream of national life. After independence more importance was attached to the cause of the tribal people. Each tribe has its own identity and each has its own distinct features and needs. Hence the study on the "Social Customs and Beliefs among the Kadar Tribes in Anamalai Region" is taken up. The topic is felt relevant and essential in understanding and explaining the social and cultural changes that are taking place among the Kadar community in Anamalai Region. The study gives some practical clues to undertake measures that lead to social improvement, social change and progress ensuring geographical spread of anti poverty programme.

* Author for correspondence 
The Tamil country or Tamil World called variously as Tamilagam or Tamil Nadu in the early literature of this linguistic country was divided into five main territorial divisions. These were named Chera Nadu, Chola Nadu, Pandiya Nadu, Tondai Nadu and Kongu Nadu [1]. Among them Kongu was a distinct and separate geographical entity. It was interposed between the Western Ghats and the hilly south of the Mysore country. The southern portion of South Kongu is covered by the Anamalai hills and their dense forests. The Anamalai hills in the Western Ghats are situated on the southern boundary of Coimbatore District of Tamil Nadu. They are divided in to the higher ranges and lower ranges. The lower ranges lying to the westward comprise the Anamalai forests. Their average elevation is not more than 2000 feet above the sea level with peaks and ridges rising to 4,000 to 5,000 feet [6]. The whole of the lower ranges with the exception of few bare and rocky peaks is covered with dense forests containing much valuable timber. Where as the higher range lying to the eastward consists of extensive open grassy hills and valleys with the shola forests similar to those on the Nilgris varying in elevation from 6000 to 8000 feet and upwards, above the sea level. The range is only separated from the Palani hills which lie to the eastward by the valley of Anjanad situated mostly in the Kerala state [2].

It is a significant segment of the Western Ghats which falls within three taluks of Coimbatore namely Pollachi, Valparai, Udumalpet, with six territorial ranges viz., Pollachi, Valparai, Ulandy, Manamboly, Udumalpet and Amaravathy. The Anamalais was declared as a Wildlife Sanctuary in 1976. In 1987, it was renamed as Indira Gandhi Wildlife Sanctuary [3]. The sanctuary is known for their rich diversity in flora and fauna and also in anthropological diversity. Out of the 36 different tribal communities listed by the Tamil Nadu Government, there are five scheduled tribes and one scheduled caste communities settled in 36 different settlements in the Sanctuary limit. Many of these settlements are located in remote, inaccessible and insensitive areas. Anamalais can rightly be described as the Anthropological Reserve of the state.

The indigenous groups living in Anamalais are the Kadar, Malasar, Malai Malasar, Pulaiyar, Muduvar, and Eravalar [4]. Of these, the Eravalar constitute a small minority but generally restricted to foothills. The other hill tribes, in contrast, are spread out in different settlements, distributed over one or more ranges of the division. Among them the Kadars are the most primitive of the hill tribes in the Anamalai. Each settlement of the Kadar called as Pathy, consists of a group of ten or more huts, huddled together on the banks of a stream or an open glade within the forests. The huts are generally built of bamboo, the walls and roofs are thatched with grass and reed leaves. Anthropologists consider that apart from the Kadar who has certain Australoid features, the rest of the hill tribes in the Anamalais are for racial purposes indistinguishable from the plainsmen in the adjoining areas. The present differences in the social customs and the manners between the plainsmen and the tribes are believed to be the result of long period of isolation in the hills.

The Kadar is considered as the best representative of the integrated food gathering tribes of South India. Until the Second World War, they were comparatively isolated with very little contact with others, except for the forest officers who had started highly selective teak plantations in some of their home lands. A forest tramway built by the Government for the extraction of timber swept a swathe through their territories, representing their means of contact with plain people. However, the tram way line was not supported by approaches to the forest winterland, the bulk of the community remained comparatively untouched by this development. The war efforts led to increased intensity of forestry operations particularly, after Independence the pace of converting natural forest to teak plantations was accelerated. The need for irrigation and power in Tamil Nadu resulted in the construction of a series of massive dams. This led to the opening up of the Kadar habitat to the general population. Fortunately, the area was declared wildlife sanctuary, with restrictions on forestry operations and admission of visitors restoring the extent of the isolated conditions which prevailed previously [5]. As a result of all these changes, the life style and culture of the Kadar have undergone many changes in the last fifty years.

The word, Kadar, in Malayalam, means the dweller of the forest (Plural-Kadars). The tribe obviously got the name because of their exclusively forest habitat. Various spellings have been used by earlier writers, example, "Kadir", "Kadar" etc. The Kadar have been considered as a human strain of considerable antiquity. They are short in stature, dark skinned with flat noses, and slightly thicker lips than those of the other hill tribes. A small percentage of Kadars exhibit frizzly hair, a characteristic that has led some anthropologists to affiliate them with the aboriginal 
tribes of Australia [6]. L.K.A. Iyer described their skin colour as generally dark. The noses are flat and somewhat depressed, the nasal index being 89.8 and 88 respectively for the men and women. Both men and women have dark curly hair. Their arms are proportionately long and they have deep chests which adapts them to mountaineering. They have great power of endurance and can carry heavy loads on their backs [7]. Thus Kadars of Anamalais are the primitive tribals, belonging to Proto australoid type.

Until the beginning of this century Kadar were seminomadic and wore bark clothes and they did not go nacked. Thurston described their settlements as consisting of "neatly constructed huts made of bamboo deftly split with a bill-hook..., and divided off into verandah and compartments by means of bamboo partitions". He also found them to be essentially nomadic, living in small communities and shifting from place to place in the jungle. Hence they suddenly reappear as casually as if they had only returned from a morning scroll instead of a long camping expedition [8].

\section{Habitat-Kadar}

Kadar are nomadic in nature and keep constantly shifting. Now they have settled in Erumaiparai in Ulandi Range, Nedungunru, Kavarakkal, Kadambarai, Ettukuli in Valparai Range and Sundaramkudi Palanganar in Manombally Range in Anamalai hills. Kadar colony is called a 'Padi'. Their huts are single roomed with stone or mud foundations and roofed with grass. The Kadar settlement is enriched with forest and wild life. Evergreen forests are seen around their settlement. Hopea, Calophyltum and Messua are some of the vegetations here. Cardamoms are the valuable vegetations grown here. The rare species like podo carpus wall chianus are seen here. Various climbers are also seen in the forest. There are various wild trees but Bamboo provides scope for the Kadars in doing honey collection, hunting, wood cutting and herbal collections etc.

The faunal diversity is also equally rich in Kadar settlement. Many rare species of birds like Quill, Grey Jungle Fowl, Spur Fowl, Parakeets, Lorikeets, Hornbills, Wood Peckers, King Fisher, Fish Eagle, Crested Serpent Eagle, Honey Buzzard, Kites, Owls, etc., are commonly seen. Panther, Leopard Cat, Rusty Spotted Cat, Jungle Cat, Ackal, and Felines like Tiger are the important mammalians found here. Rodents like Giant Squirrel, Porcupine, Field Mice, Sambar, Spotted Deer, Mouse Deer, Gaur, and Bison are some animals living around these settlements. Chameleon, Star Tortoise, Flapshells, Python, King Cobra, Tree Frogs, Leaping Frogs, Toads are the most common reptiles living here [9]. Kadar settlements are frequently disturbed by elephants which are the most common animals in the area.

\section{Tribal Society}

The head of the settlement of Kadar is called as Moopan. The post of Moopan is not hereditary. Any one of the elders of their society is selected as Moopan who is the sole authority of conducting, fixing the date and presiding over the functions. He acts as a chief of the family rituals, settles the disputes and dispenses justice. To advise and assist him, there is a 'Council of Elders' in the settlement which hears the argument relating to marriages, disobedience and immoral conduct. But this council is not in practice today. The Muppatti, wife of Moopan heads the Kadar women. In former times, when their tribe was more numerous, they had a headman who possessed a stick as the symbol of their office. This stick had a sliver band [10].

\section{Marriage and Family}

Marriage is the source of the family, the safeguard of private and public morals, and the strength of the nation. There are three motives which lead to marriage-mutual sympathy, the desire of progeny and the need for mutual aid in the struggle for existence. Primitive marriage as dictated by the inexorable population need grew out of the family rather than the family out of marriage. No uniform family pattern can be discovered among the primitive tribes of Anamalai region. Though there is great freedom in the marriage regulation of the tribes, most tribes hold to the conviction that some form of marriage is essential for the survival of the tribe, for the rearing of children and for happiness in future. Among the Kadar, marriage is prohibited within the settlement. Cross-cousin marriage is not prohibited even though consanguineous marriages are not permitted. Patrilateral cross cousin marriage is preferred to matrilateral. Levirate and Sororate marriages are nowadays practiced. They are not conventionally approved. Instances of polygamous and polyandrous marriages have also been noticed of late. Marriage by service, Kudithamasikkal is very common. The parents of the girl are presented with clothes when the actual marriage ceremony takes place [11]. 


\section{Life Cycle Rituals among the Kadar}

\subsection{Child Birth}

A pregnant woman is generally confined to a seclusion shed called, Eathepatti, when the labour pains start. In the case of difficult labour, it is believed that an evil spirit is haunting the woman and a magician, Thevamali is consulted to exorcise it. Some professional midwives are found among the Kadar. Just after the pains start, the belly is fomented by the midwife. Immediately after the birth, the child is bathed in warm water. The mother confines herself to the seclusion hut for 10 days during which she takes hot water bath after applying a turmeric paste and coconut oil on the body. On the $10^{\text {th }}$ day, she is removed to another seclusion hut, where she remains for 80 days during which she is prohibited from doing any manual work even in the kitchen. The Kadar thus observes 91 days birth pollution. The naming ceremony is performed on that day.

\subsection{Family Planning}

Kadar use family planning with the help of herbal medicines. The roots of Konna, Venga and Veetti are used for making capsules for family planning. The roots are collected from the western side of the above trees and made to powder. A piece of deer horn is also powdered and added. The powdering is done on a clean rock. Capsules are then prepared. In order to prevent pregnancy, a capsule is given to the Kadar woman on the $8^{\text {th }}, 9^{\text {th }}$ and $10^{\text {th }}$ day following her monthly period. The capsule is called Nallaka in their language. It is taken in an empty stomach. She is not allowed to take tamarind and lemon for two weeks [11]. This is the way they prevent pregnancy.

\subsection{Puberty}

When a girl attains puberty, she is confined to a seclusion hut for seven days, where she is assisted by a few girls of her settlement who have not yet attained puberty. Every day, the girl is given bath after applying turmeric paste and coconut oil on the body. On the seventh day she takes a ceremonial purificatory bath and becomes free from pollution. A girl under puberty is prohibited from taking bath in a stream because it is believed that this would pollute the water. After the purificatory bath on the $7^{\text {th }}$ day, the girl is dressed up in new clothes and brought to the courtyard of her hut. All the members of the settlement assemble and give presents of money to her.

\subsection{Culture and Beliefs}

The culture of the people is the sum total of all their customs, activities and beliefs. Food is the urgent and recurrent need of man. It indicates his activities in relation to land at every stage of economic development. Among the Kadars, the staple food now-a-days is rice, supplemented with roots and greens. Rice was formerly a luxury, but now they get it as part of wages and from the shops. The roots and greens are collected from the forest and used to be once the major source of food. It is known as thettam. A root of tuber or even a beehive spotted by one Kadar individual cannot be exploited by any other Kadan. The roots and greens collected by the Kadar include Nora, Thali, Nore, Chandra, Kandmira, etc. They also collect fruits of wild jack, cashew and mango. These are bartered for rice, tobacco, cloth, beedi, etc. Honey, Chinikkai, Pathiripu, Marohikkuru, Kakkankay, Chinikkai, Pathiripu, Marohikkuru, Pulinjaka, Malamanjal (wild tumeric), etc., are collected from December to April. Ginger, Cardamom, etc, are collected from May to September. Thelly, Fruits of Mimosa, Inchapatta, Matti, Cane, Aralithiri, Arrowroot, Mellikka, Mattipal and Lemongrass are collected throughout the year. These items used to be sold or bartered to the contractors and exchanged for food items. Now-a-days, the Co-operative Societies have taken over this role. Another favourite item is tapioca, which they grow in their own kitchen gardens. Thurston described a variety in the dietary which would be the envy of a present day Kadar. It included succulent roots, bamboo, sheep, fowls, pythons, deer porcupines, field rats, wild pigs, monkeys, etc., which gave each Kadar a hard and wellnourished body [12]. These are all now strictly protected by the forest department.

Kadar women who inhabitat the interior forest put on a loin cloth and a bodice, while those living near the roads and villages put on lion cloth and blouses. Some of the women wear sarees and blouses. They are not fond of ornaments. The women wear Thodu (ear ring) formed of a roll of palm leaf ornamented with the red and black beads, Mukkuthi (nose ring), Manimala and Kailumala (beed necklaces), cheap metal or plastic necklaces and bangles of similar materials. A few Kadar men wear ear rings. 


\subsection{The Kadar Comb}

The 'Kadar Comb' is one of the ideal products of their craft. Two types are made, one with four prongs and the other with numerous prongs. Both are struck with the hair sidewise and from the back part of the head. But now they struck ordinary comb also. Thurston drew attention to the similarity of the designs carved on the bamboo combs of the Kadar with those of the Negritos of Malacca [13]. According to him a Kadar man should always make a comb and present it to his intended wife just before the marriage or at the conclusion of the marriage ceremony and the young men vie with each other as to who can make the nicest comb. But this habit is not common at present.

\subsection{Forest and Hill Deities}

Ancestor worship is one of the great branches of the religion of mankind. Its principles keep up the social relations of the tribal people too. Almost all the tribes venerate and worship their ancestors. The Kadar believes that their ancestors and the dead are their best protectors from danger and come to their assistance when they are in misery and difficulties. Before they go out on a honey collecting expedition they make an offering to their ancestors. They also invoke their ancestors when they go out to hunt or to collect jungle produce. They believe that the ancestors help them to find abundant food and protect them against wild animals. Haunting spirits are also worshipped by them. The tribes of Anaimalai venerate hill deities whom they locate on the crests and / tops of hills. Thus the popular god of these tribes is Mala Deivom, God of the Hills. The Kadar worship Mala Deivom or Makannnimar (sylvan deities). Apart from the Malaideivam, there seems to be a lot of deities worshipped among the Kadar like Pakutlatha, Athuvisariyamma, Vanathavath, Iyappasamy. A stone set up beneath a teak tree called as Kannimara and Masaniyatha, a female figure which are also worshipped. They also worship Kali, Ayyappan and Malavazhi, the ruler of the hills. Bell, lamp, pot incense are used as the pooja items. Added to these they also use their weapons like scythe, spear etc., as pooja items to worship. The poojas are conducted by a man called ur-poorsari. He sings songs called 'Padam Solluthal' in order to drive away diseases, evil spirits etc. Raised platform under the shade of a tree is considered as the temple. The temples are in the form of hut. The images of their deities are in the shaped stone form. Spear, Scythed arrow are placed near the deities in the temple.
Onam and Vishu are the important festivals celebrated by them.

\subsection{Music and Dance}

Music and dance are indigenous and even the elders participate in it. The Kadars have developed well formed diverse dance movements and orchestra. The musical instruments are made by them. The leather instruments made of wooden plank are used. The leather from black monkey is used to make instruments. The flutes are made from Vengai and Jack trees. The seven or nine holed flutes are called by them 'Karumbu'. When compared to other instruments it is hard to play. The main instruments of the Kadar are 'Udukku', 'Kendai' and 'Urumi'. The Kendai looks like a cylinder, which is played with stick called 'Kendai Kuchi'. In some occasions, Kendai is played along with flute. Urumi is also made from Vengai tree. It is smaller than Kendai and played on both the sides with sticks.

When the two musical instruments are played the Kadar men and women dance according to the tune. Kummi, Kollattam, Oyilattam are the important dances performed by the ladies. The dances played by the gents are called kollattam, pandriyattam and mandhiattam. Kummi is played by the ladies without instruments. They stand round and sing songs merrily. The term Kollattam in Kadar language is called 'Koliattam'. The ladies perform this slowly while the gents do faster. Oyilattam resembles the folk dances of plains, where the dancer should perform in the same standing position. Pandriyattam is performed by the Kadars along with music. It indicates the hunting of pigs. Mandhiattam is also performed along with the music imagining himself as monkey. This dance denotes their hunting profession.

\section{Conclusion}

In the family of the tribes in this region, male members exercise dominant authority over the family members while women occupy a subordinate position. Wedding ceremonies vary from one tribe to the other. By and large all these tribes permit the wedding at an early age for the principal reason that the source of happiness consists of the solace of a domestic life. But many of the rites and formalities are similar among the tribes. The life of these tribes revolves around the pastoral and agrarian economy. No fundamental innovations were introduced in the agricultural work by them inspite of advancement 
in science and technology of the present day. There are numerous obstacles in selling their agricultural products and minor forest product collections. The tribals were provided employment opportunities by the forest department as anti poaching watchers through funds released under several Tribal Sub Plan schemes. Some of them are also given permanent appointment as forest watchers on regular pay. But only minimum number of tribals is benefited by this opportunity. Having no higher ambition in life, the inhabitants cherish a strong tendency to remain contended and happy with available resources. Blind faith, absence of education and lack of contact with the rest of the society seem to be the reasons for the unchanging belief and practices.

The tribes are also the citizens of India and hence the promotion of their welfare is of equal importance. What is needed to improve the social, economic and cultural condition of the tribes in the Anamalais is educating them through all means. This is an imperative necessity to lift them. Both the governments, individuals and service organizations must jointly formulate certain plans and programmes to improve the economic conditions of the tribes and bring them to a state of secured living. To realize this, the housing, educational, medical, agricultural, trade, communication and banking facilities can be provided by the said agencies generously. The tribes want improvement without being disturbed. Their age old customs should be respected and their local rights should be protected. The government should consider their basic requirements and demands.

The tasks that can be imposed on our government and non-government organizations are as follows: The first is to preserve, strengthen and develop all that is best in the tribal society, culture, art and language. The tribes like to strengthen themselves from the contaminating influences of modern civilization and like to protect themselves not only economically, but culturally, from outside exploitation. The second is to protect the tribal economic rights. The third is to unite and integrate the tribes of Anamalai region with the other tribes of India as a whole. The government of India should help the tribal people to develop according to their own culture and tradition.

\section{References}

1. Vaidyanathan K.S. The Ancient Geography of the Kongu Country, Kalaimahal Meenakshisundaram Archaeological Learning and Research Centre, Erode, 1983, p. 6.

2. Ramamurthy V. History of Kongu, International Society for the Investigation of Ancient Civilization, Madras, 1986, pp. 26-27.

3. Office Record, Indira Gandhi Wildlife Sanctuary, Pollachi.

4. The Encyclopaedia of Dravidian Tribes, Vol. III, International School of Dravidian Linguistics, 1996, p. 367.

5. Chouthry, M. Tribals of Ancient India, Indian Museum, Calcutta, 1977, p. 76.

6. Gunasekaran K.A. Tamilaga Malaiyina Makkal, (Tamil), New Century Book House, Chennai, 1993, p. 9.

7. Ananthakrishna I.L.K. The Tribes and Castes of Cochin, (Reprint 1981) Cosmo Publications, Delhi, 1906, p. 123.

8. Thurston E. Castes and Tribes of Southern India, Vol. VIII, Asian Educational Services, Delhi, 1987, p. 10.

9. Tribal and Forest Development Project, Format-II, Indira Gandhi Wildlife Sanctuary, Pollachi.

10. Fuchs S. Aboriginal Tribes of India, Macmillan Company of India Ltd., Bombay, 1973, pp. 257-258.

11. Personal interview with Karuppama, Kadar woman, age 62 .

12. Thurston E. Castes and Tribes of Southern India, Vol. VIII, Asian Educational Services, Delhi, 1987, p. 17.

13. Thurston E. Castes and Tribes of Southern India, Vol. VIII, Asian Educational Services, Delhi, 1987, p. 27. 